\title{
Adoção internacional: realidades, conceitos e preconceitos
}

\author{
International adoption: realities, concepts and \\ prejudices
}

\author{
Elizane Lunardon Pereira*
}

A adoção por estrangeiros é tema repleto de mitos e folclores. A verdade sobre sua prática e ideologia, geralmente esconde sua grandeza. [...] Aqueles que consideram que a adoção por estrangeiros desconstitui a nacionalidade e a cidadania ainda não atentaram para a importância da colocação de uma criança em uma família.

Liberati, 2003:13.

\begin{abstract}
Resumo: A adoção representa um tema passível de grande discussão e aprofundamento, ainda mais ao se tratar da adoção por estrangeiros. Este estudo pretende refletir sobre realidades que envolvem o encaminhamento de crianças e adolescentes à adoção internacional, bem como a aplicação dessa medida enquanto mecanismo garantidor de direitos. Para tanto, realiza reflexões sobre referencial teórico que trata da adoção, sobre legislações nacionais e internacionais e análises de cartas escritas por adotados, enviadas ao organismo (AFN/PR) responsável pela mediação da adoção por italianos. Além disso, apresenta análise entre procedimentos legais e visão societária da adoção. O intuito principal está em verificar o que a experiência adotiva significou para esses sujeitos após alguns anos da inserção no novo país.
\end{abstract}

Palavras-chave: Adoção internacional. Paternidade/filiação. Afirmação de direitos.

\begin{abstract}
Adoption is a topic subject that generates a lot of discussion and deepening thought, even more the case of the adoption by foreigners. This study aims to reflect on the realities that involve referral of children and adolescents to international adoption and the application of this measure as a mechanism guarantor of the rights. The study presents theoretical reflections on dealing with the adoption of national laws and international analyzes letters written by who were adopted to the agency (AFN / PR) responsible for mediating the adoption by Italians. Moreover, it presents legal and vision analysis procedures of corporate adoption. The main intention is to look at what the experience meant to foster these guys after a few years of entering the new country.
\end{abstract}

Keywords: International adoption. Fatherhood/sonship. Affirmation of rights. 


\section{Introdução}

A adoção internacional vem se tornando uma prática significativamente criticada por alguns segmentos. Todavia, observa-se que parte daqueles que a censuram possuem pouco ou nenhum vínculo direto com essa prática e, dessa forma, criticam algo ao qual seu conhecimento encontra-se limitado.

Aplicar censura ao que não se conhece, além de pouco ético, pode também não ser construtivo, visto que críticas não enriquecidas de contribuições concretas, eficientes e eficazes agregam quase nada à melhoria da realidade.

O presente trabalho parte da experiência prática com a adoção internacional para dialogar e refletir acerca de aspectos que podem ser melhorados para beneficiar também a adoção por casais nacionais, desde que favoreça prioritariamente aos interesses da criança. Todavia, o foco de estudo está nas adoções em que não há casal nacional interessado, portanto, nas adoções internacionais (ECA art. $50 \S 6^{\circ}$ e $10^{\circ}$ e art. 51).

Não se pretende defender incondicionalmente a prática da adoção. O que se almeja é construir esclarecimentos sobre o tema, considerando que a adoção por estrangeiros é legalmente reconhecida e se aplica aos casos em que não houve possibilidade de retorno à família de origem ou à família extensa e também não há casais nacionais interessados naquela adoção.

A necessidade de escrever este trabalho surgiu do entendimento de que ao menos algumas críticas precisam ser esclarecidas. Não se deseja ignorar a existência de problemas pertinentes à adoção internacional. $O$ que se aspira é refletir um pouco sobre as realidades que envolvem esse assunto, além de chamar a atenção para o fato de que muitas das censuras efetuadas perdem seu fundamento porque não estão centradas no foco do problema e, com isso, as soluções apresentadas podem perder sua efetividade.

Diversas críticas são efetuadas em virtude do desconhecimento sobre como estão as crianças/adolescentes após sua chegada ao exterior. Porém, não se verifica que os relatórios pós-adotivos são apresentados pelo organismo credenciado que acompanhou o caso. Esses relatórios são enviados às Comarcas de origem da criança/ adolescente, à Comissão Estadual Judiciária de Adoção (CEJA/PR) e à Autoridade Central, em Brasília, em geral, por pelo menos dois anos a partir do ingresso do filho no novo país.

Se tais relatórios não são expostos à população em geral, ou pelo menos às pessoas que de algum modo acompanharam as crianças antes da adoção, isso se justifica pelo chamado segredo de justiça. Desse modo, se as pessoas se encontram insatisfeitas pela ausência de notícias, é a correta ou errônea aplicação do segredo de justiça que deve ser questionada e não apenas a falta de notícias por si só.

Há casos em que críticas são efetuadas à adoção em virtude de processos mal examinados, nos quais se destituem crianças/adolescentes que possivelmente teriam possibilidade de retornar ao convívio familiar ou permanecer com a família extensa, mas que acabam sendo colocadas em famílias substitutas.

Nesse caso, a adoção não é o "mal" em si, pois, se existem destituições mal fundamentadas, há que se cuidar mais da formação dos profissionais envolvidos com tal decisão, sejam estes juízes, promotores, assistentes sociais, psicólogos, conselheiros tutelares ou demais profissionais que acabam desvirtuando o sentindo da lei e aplicando-a de modo a não privilegiar concretamente o maior interesse da criança.

Outro aspecto consideravelmente questionado diz respeito à separação de irmãos e ao afastamento da criança de seu país de origem através da adoção internacional. Contudo, não se considera que a formação dos casais nacionais ainda se processa de maneira superficial em diversos casos e, portanto, encontra-se insuficiente para atender essa demanda de grupos de irmãos e crianças maiores. Destarte, essa alternativa ainda não se apresenta suficiente para responder devidamente a tal demanda.

Ainda não se conseguiu atualizar o entendimento social da adoção enquanto um processo de paternidade/maternidade tal qual a gestação: do qual resulta o filho, sem discriminação ou distinção. O processo de adoção não existe apenas para suprir a necessidade de pessoas ou casais de tornarem-se pais, mas para dar aos filhos a possibilidade de serem filhos. Também não existe para autopromover as "pessoas de bom coração" que saem pelas ruas proclamando que fizeram a boa ação de terem um filho 
adotivo: "meu filho adotivo". Os filhos não são estandartes, são pessoas, com sentimentos e necessidades afetivas como os outros.

Portanto, quando críticas são formuladas há que se ter cuidado para observar a centralidade da questão. Pode se tornar mais simples encontrar um "problema" e "descarregar" nele todas as "culpas" do que, propriamente, ajustar o foco para onde se encontram de fato as raízes do assunto.

Situações mal interpretadas podem acarretar distúrbios de visão ou de entendimento sobre os fatos e precisam ser corrigidas para não incorrer em injustiças.

\section{O processo de paternidade e filiação adotiva}

A palavra adoção é proveniente do latim adoptatio, que, segundo Weber (1999), está associada a considerar, olhar para, escolher, perfilhar. Houaiss (2001) estabelece a origem da palavra no século XV. Amim e Menandro (2007, p.241) afirmam que registros "disponíveis indicam que a adoção é praticada há muitos séculos, assumindo diferentes significados, características e objetivos ao longo da história e em diferentes culturas".

\section{Breve histórico da adoção}

Segundo Vargas (1998), a adoção é uma prática antiga dos países de direito romano, os quais sustentavam legalmente a ideia de filiação atribuída através de um certificado aos adotantes, anulando a filiação biológica e garantindo ao adotado a aquisição do sobrenome da família.

Através desse princípio, por exemplo, foi que reinou por mais de um século a linhagem imperial de Júlio César, que adotou Otávio, o "Augusto", e teve como descendentes: Tibério, Calígula, Nero, Trajano, os Antonios e Marco Aurélio. Também Napoleão Bonaparte, cuja esposa ficara estéril, garantiu através do Código Civil todos os direitos aos filhos adotados. Porém, tratava-se de uma lei bastante restritiva.

Embora existam registros de adoção desde a antiguidade, Weber (2001) observa que apenas após a Primeira Guerra Mundial, com o imenso número de crianças órfãs e abandonadas, a adoção começou a voltar-se mais para os interesses do adotado.
Ainda assim, Gomide (1999) apregoa que a adoção, de modo particular no Brasil, foi tradicionalmente encarada como uma via de mão única, na qual apenas os anseios dos adotantes buscavam ser atendidos.

Esse método de adoção no qual o que se busca é suprir os interesses dos pais é conhecido como adoção clássica: seleciona, para ser adotado, preferencialmente, um recém-nascido com as características físicas semelhantes às dos adotantes. A motivação para esse evento geralmente vem da esterilidade ou infertilidade e procura imitar uma família biológica como alternativa para "solucionar dificuldades de casais sem filhos." (AMIM; MENANDRO, 2007, p. 242).

\section{A adoção e as Relações de Família}

O desejo de ter filhos também está vinculado ao fato de que o ser humano tem uma natureza gregária, portanto, é também através dos grupos sociais que se garante a sobrevivência da espécie. Destarte, a família apresenta-se há muito tempo como um significativo espaço de sociabilidade primária dos indivíduos, a partir do qual se compõem agrupamentos mais extensos. Entenda-se por família o grupo de pessoas que convive no mesmo espaço, independente dos arranjos.

$\mathrm{O}$ anseio de pertencimento e a necessidade de sentir-se membro de uma família emerge nas crianças e adolescentes também em virtude da necessidade que o ser humano tem de se relacionar e estar próximo dos outros. Dessa forma, o sentimento de pertença a uma família não se resume em mero instinto, pois resulta de uma vivência construída de maneira íntima, ou pelo menos próxima, e de relacionamentos contínuos.

Dentre as atribuições pertinentes à família destacam-se a proteção e a formação de seus membros, especialmente as crianças e adolescentes. A relação de dependência entre os filhos e seus pais ou responsáveis "faz com que estes sejam extremamente importantes para a criança durante o seu processo de desenvolvimento." (LANE, 1989, p. 43).

Evidencia-se que a responsabilidade de criar filhos passa pelo desejo dos casais de serem pais e pelas relações estabelecidas conjugal e socialmente, sendo que esses fatores influenciam na formação da personalidade dos filhos. 


\section{O processo de filiação}

No processo de adoção, tanto os filhos quanto os pais são adotados, pois partem de uma idealização de vivência em família para uma realidade concreta na qual se revelam as pessoas tal como são. Nesse sentido, os adultos deixam de viver só para si ou seu companheiro e passam, repentinamente, a um processo de divisão do tempo e da atenção para com outros sujeitos, geralmente bastante carentes afetivamente: os filhos.

Os filhos podem testar de várias formas "o amor de seus pais adotivos para poder ter certeza do mesmo, de que não haverá um novo abandono. Cabe ao adulto se preparar para receber este novo membro na família." (SOUZA, 2006, p.13).

Ser filho adotivo é ser filho. O ECA, art. 41 , estabelece que a adoção atribui a condição de filho ao adotado, com os mesmos direitos e deveres. Embora muitas vezes haja lacunas na história de vida do filho, as quais podem vir a gerar curiosidade, dúvidas e fantasias, o laço de filiação a ser desenvolvido configura-se como um fator indispensável à consolidação da família.

As filiações adotivas ou consanguíneas representam antes de tudo filiação. Basicamente, o que as diferencia originalmente é a gestação, o fato de deixar de pertencer aos primeiros pais ou familiares e o acolhimento institucional. Em casos de acolhimento institucional, é possível que existam lembranças da vida familiar precedente e esses fatores, o que pode influenciar no processo de inserção em uma família adotiva. Porém, o simples fato de recordar não torna a adoção uma realidade por si só mais difícil ou impossível.

A filiação adotiva é legítima, possuindo o mesmo valor jurídico do que a filiação biológica, além de constituir-se como uma realidade social e psicológica. Mas ao se falar em adoção, a realidade do abandono emerge potencialmente vinculada. $\mathrm{O}$ abandono pode ser caracterizado como a perda, pelo filho, do direito de permanecer no seio de uma família.

Nesse sentido, a colocação em família substituta prevê:

[...] a integração em um lar e a possibilidade de manter, estabelecer ou restabelecer laços afetivos entre a criança e figuras parentais, podendo ser esta a solução [...] que pode oferecer as melhores condições e apoio necessários à criança para que ela se desenvolva. (VARGAS, 1998, p. 18).

Então, preparar-se para ter um filho envolve tanto questões socialmente estabelecidas como também certo conhecimento sobre si, seu entorno e o mundo, numa dinâmica contínua, visto que cada fase do filho requer novas reflexões. O ser humano passa continuamente por mudanças, influenciado também pelo ambiente externo.

Em um processo de adoção, a preparação e as motivações não são diferentes, visto que se trata de acolher um filho que pertencerá à família. Portanto, nos processos de adoção é fundamental uma preparação adequada que abra horizontes e esclareça sobre aspectos até então mal conhecidos acerca do futuro filho.

Lane (1989) afirma que as relações de poder que caracterizam os papéis familiares são apresentadas como condições naturais e necessárias para a sobrevivência dos filhos histórica, social e fisicamente.

Em se tratando de adoção de crianças maiores, também em virtude de nossa cultura atual, as chances de inserção em uma família diminuem conforme a idade aumenta. Contudo, o sucesso do estabelecimento de vínculos com futuros pais, tanto nacional como internacionalmente, depende de vários fatores.

Em situações nas quais a criança sofreu ruptura com a sua família biológica, é possível restabelecer novos vínculos que a ajudarão a "reconstruir o seu eu primário a partir das novas representações dela própria, das quais participa, [...] a interiorização das novas imagens parentais." (VARGAS, 1998, p. 36).

O desenvolvimento infantil saudável passa pelo crescimento em uma família que, dentre outras coisas, acolha e eduque. O processo de construção de vínculos afetivos para crianças que passaram por maus-tratos pode ser mais forte que qualquer outra experiência negativa que a criança tenha vivenciado. Embora esse processo possa não ser fácil, tanto para os pais quanto para os filhos, pode significar a chance de construir uma nova história de vida à criança que adquire um lar.

Para tanto, a formação adequada dos pais e o acompanhamento profissional, princi- 
palmente por assistentes sociais e psicólogos, contribuem muito na compreensão das possíveis dificuldades a serem enfrentadas, pois objetivam viabilizar um maior entendimento da situação.

A legislação consagra a necessidade da participação de equipe profissional nos processos de adoção. Tal acompanhamento não constitui mera formalidade, conforme o ECA, art. $50, \S \S 1^{\circ}, 2^{\circ}, 3^{\circ}$ e $4^{\circ}$, e art. $46, \S 4^{\circ}$. Contudo, o que se vislumbra na prática é que essa estrutura pessoal fundamental ao longo de todo o processo nem sempre está presente como prevê a lei.

A presença dos profissionais se faz necessária no processo de orientação e formação dos futuros pais, dos futuros filhos, ao longo do estágio de convivência entre ambos, bem como após a sentença de adoção, para acompanhamento do processo de adaptação e as eventuais dificuldades que podem emergir e que precisam ser seguidas devidamente.

O acompanhamento profissional colabora para o estabelecimento de maiores esclarecimentos, além de instrução, informação, desmistificação de estereótipos e preconceitos. O desvelamento de realidades, antes encobertas pela falta de conhecimento adequado sobre a situação, contribui na mudança de motivações e expectativas. Assim sendo, interfere na leitura dos anseios ou necessidades presentes nas pessoas que se cadastram para o processo de adoção.

A adoção diz respeito ao estabelecimento de vínculos parentais e este não pode ocorrer de qualquer maneira. Faz-se imprescindível o acompanhamento de uma equipe interdisciplinar especializada a fim de que a leitura da realidade e dos comportamentos seja efetuada de modo a favorecer concretamente o processo, ou mesmo para evidenciar situações nas quais se indica o rompimento.

A equipe profissional atua também para fornecer respaldo às decisões judiciais, visto que possui a aptidão técnica necessária para "sistematizar conhecimentos acerca das dimensões da realidade social que se fazem presentes no cotidiano de trabalho." (CFESS, 2005, p. 13).

Portanto, a atuação profissional, embora não se reduza a apenas isso, pode ser expressa para "oferecer subsídios técnico-científicos" capazes de possibilitar "ao magistrado a aplicação da lei com maior segurança, reduzindo-se a possibilidade da prática de erros ou injustiças." (CFESS, 2005, p. 18).

O ECA aponta, no artigo 151, para a necessidade do trabalho da equipe interprofissional, destacando que compete a esta "fornecer subsídios por escrito, mediante laudos, ou verbalmente, na audiência, e bem assim desenvolver trabalhos de aconselhamento, orientação, encaminhamento, prevenção e outros [...]".

Pode-se afirmar, mais especificamente a respeito do profissional de serviço social, que este:

Por meio de observações, entrevistas, pesquisas documentais e bibliográficas, ele constrói o estudo social, ou seja, constrói um saber a respeito da população usuária dos serviços judiciários. Um saber que pode se constituir numa verdade. As pessoas são examinadas, avaliadas, suas vidas e condutas interpretadas e registradas, construindo-se, assim, uma verdade a respeito delas. (CFESS, p. 28).

Os documentos elaborados, sejam relatórios, laudos ou pareceres sociais, "transformam-se em instrumentos de [...] saber, convertido em poder de verdade, que contribui para a definição do futuro de crianças, adolescentes e famílias, na medida em que é utilizado como uma das provas que [...] podem compor os autos." (CFESS, p.28).

Importante destacar que, embora o magistrado represente uma autoridade, é assegurado ao profissional "a livre manifestação do ponto de vista técnico." (ECA, art. 151). Portanto, o parecer do profissional deve respaldar-se em seus conhecimentos e leituras da realidade e nas legislações afins.

O profissional, mais especificamente o assistente social,

é autônomo no exercício de suas funções, o que se legitima, fundamentalmente, pela competência teórico-metodológica e ético-política por meio da qual executa o seu trabalho. Autonomia garantida legalmente, com base no Código de Ética Profissional, na lei que regulamenta a profissão, no próprio ECA, na legislação civil. (CFESS, p. 28-29).

Portanto, o processo judicial tem que contar com o suporte técnico especializado, visto que o conhecimento específico do profissional não pode ser substituído. 


\section{Aspectos legislativos do direito da criança e do adolescente e a adoção internacional}

Ainda que de maneira embrionária, a gênese do instituto da adoção internacional, de acordo com Davies (1990), pode estar situado em 1627 , período em que uma significativa quantidade de crianças inglesas foi transportada de navio para o sul dos Estados Unidos, com a finalidade de serem integradas a famílias de colonos. Tratava-se de meninos e meninas órfãos, alguns abandonados e outros que tinham a adoção autorizada por seus pais, para se tornarem aprendizes em famílias de artesãos.

Contudo, as legislações internacionais existentes até o momento não abrangiam ainda a temática dos direitos das crianças e adolescentes, especialmente no que diz respeito à "transferência" de um país ao outro. Segundo Veronese \& Petry, é a partir da Declaração de Genebra de 1924 que:

inicia-se um período que se estende por todo o século XX, marcado por uma preocupação: os documentos internacionais devem reconhecer que a infância é merecedora de uma atenção diferenciada o que, aliás, foi exatamente declarado na citada Convenção: a "necessidade de proclamar à criança uma proteção especial". (2004, p. 25).

Após essa Declaração, surgiram também outras normativas internacionais, como a Declaração Universal dos Direitos Humanos, documento das Nações Unidas, de 1948. Além de ensaiar um novo conceito diante da dignidade do ser humano, destaca também à criança "o direito a cuidados e assistência especiais".

Veronese \& Petry recordam que a Declaração Universal dos Direitos da Criança, de 1959, traz como Segundo Princípio:

A criança gozará de proteção especial e disporá de oportunidades e serviços, a serem estabelecidos em lei por outros meios, de modo que possa desenvolver-se física, mental, moral, espiritual e socialmente de forma saudável e normal, assim como em condições de liberdade e dignidade. Ao promulgar leis com este fim, a consideração fundamental a que se atenderá será o interesse superior da criança.

No que diz respeito às normativas internacionais, a Declaração Universal dos Direitos da Criança inaugura o reconhecimento de que a criança merece atenção especial da família e da sociedade. "Os princípios nela enunciados resultam numa paulatina e significativa mudança, objetivando proteger de forma efetiva os infantes." (VERONESE; PETRY, 2004, p.25).

Passa a estabelecer-se a partir de então, no universo da infância e juventude, uma visão bem diferente daquela existente até então, que era a de praticamente não considerar a criança como uma pessoa. A nova concepção, por sua vez, passa dos cuidados e atenções especiais imprescindíveis ao "melhor interesse da criança".

Ao se pensar nos direitos da criança, a adoção internacional também começa a adquirir espaços de discussão. Nesse sentido,

passou a ter maior relevância com o crescimento das nações e isto foi mais intenso e profundo após a Segunda Guerra Mundial. A partir daí que a comunidade internacional entende como importante dar uma maior atenção à questão da exclusão e do abandono social, os quais caminhavam em paralelo ao desenvolvimento industrial. [...] Assim, por iniciativa da própria ONU, em 1960, o tema da adoção por estrangeiros tornou-se objeto de discussões num seminário realizado em Leysin, Suíça. (VERONESE; PETRY, 2004, p. 21).

Como fruto desse seminário resultou um estudo no qual se definem os primeiros princípios da adoção internacional - "Fundamental Principles for intercontry adoption - Leysin". Já a partir desse documento compreende-se a adoção internacional como medida excepcional, aplicável apenas quando se configura o bem-estar da criança. Além disso, a prioridade deveria ser dada à adoção nacional.

Em termos de normativas internacionais relativas ao direito da infância, há que se considerar também o Pacto de Direitos Civis e Políticos, especialmente no art. $23, \S 1^{\circ}$ e art. 24, $\S \S 1^{\circ}, 2^{\circ}$ e $3^{\circ}$. E o Pacto de Direitos Econômicos, Sociais e Culturais, art. $10, \S \S 1^{\circ}, 2^{\circ}$ e $3^{\circ}$. Ambos os pactos datam de 1966.

No âmbito dos tratados e convenções internacionais, torna-se relevante destacar ainda: Convenção Relativa à Competência das Autoridades e à Lei Aplicável em Matéria de Proteção de Menores (1961), Convenção de Estrasburgo (1967), Convenção Americana 
sobre os Direitos Humanos (1969), Convenção Interamericana sobre Restituição Internacional de Menores (1979), Convenção sobre os Aspectos Civis do Sequestro Internacional de Crianças (1980), Reunião do Panamá (1984), Reunião de Acapulco (1985), Convenção Interamericana sobre Conflitos de Leis em Matéria de Adoção de Menores (1985), Convenção Internacional dos Direitos da Criança (1989) e Convenção Interamericana sobre Tráfico Internacional de Menores (1994).

Em termos nacionais, a regulamentação das leis relativas à infância foi estabelecida precedentemente pelos Códigos de Menores (1927 e 1979). A doutrina do Código de Menores confundia "na mesma situação irregular abandonados, maltratados, vítimas e infratores. Causa perplexidade que se considerasse em situação irregular o menino abandonado ou maltratado pelo pai, ou [...] privado de saúde ou da educação por incúria do Estado." (AMARAL E SILVA, 1994, p.37).

Portanto, ao restringir toda a abordagem aos que se encontravam em "situação irregular", o Código de Menores, sobretudo o de 1979, conforme afirmam Veronese e Petry, implicava uma leitura que inferiorizava, coisificava e menorizava a infância (2004, p. 118).

Essa Doutrina da Situação Irregular, utilizada pelo extinto Código de Menores, culpabilizava a família (pobre e estigmatizada como "desestruturada") em quase todas as situações. Em função disso retirava suas crianças e adolescentes e institucionalizava-os, impondo-lhes a dor da separação ao invés de um investimento concreto na família a fim de que essa pudesse emancipar-se.

É principalmente a partir da década de 1980 que os questionamentos sobre o espaço que crianças e adolescentes ocupavam no sistema judiciário brasileiro começam a desencadear, sobretudo impulsionados por um forte movimento social. Um dos principais atores dessa mobilização foi o Movimento Nacional dos Meninos e Meninas de Rua. Além desse, outras organizações de proteção à infância também contribuíram impulsionando um processo de luta pelo exercício da cidadania.

Isso permitiu que a Constituição da República Federativa do Brasil, de 1988 (CF/88), considerasse várias garantias relativas à infância e juventude, além de impulsionar a posterior criação da Lei nº. 8.069/90: o Estatuto da Criança e do Adolescente (ECA). O Estatuto busca romper com o modelo anterior e reconhece o importante espaço da família na construção das relações afetivas, de educação e valores. Portanto, reconhece o papel significativo da família, ao invés de procurar apenas culpá-la e puni-la.

No que diz respeito à adoção por estrangeiros, é também a partir dos anos oitenta que o Brasil começa a constituir uma nova dimensão sobre essa prática. Regulamentações passam a ser estabelecidas com a finalidade de: coibir o tráfico de crianças; estabelecer um pacto de confiança entre os países; estampar legalidade nos processos a partir do monitoramento pelo Poder Judiciário; propiciar maior credibilidade aos adotantes e aos adotados; além de apresentar-se como uma alternativa contra a permanência de crianças/adolescentes em instituições de acolhimento por tempo prolongado, devido à ausência de pais/mães residentes no Brasil interessados na adoção desses sujeitos.

A CF/88 concebe a criança e o adolescente como pessoas portadoras de direitos que, por sua natureza específica, necessitam de proteção integral, diferenciada e especializada. Nestes termos, o direito à convivência familiar $\mathrm{e}$ comunitária passa a configurar-se como direito fundamental, o qual deve ser assegurado pela família, pela sociedade e pelo Estado.

A Constituição (art. 227, § $6^{\circ}$ ) também passa a determinar que os filhos, oriundos ou não da relação de casamento ou adotivos, têm os mesmos direitos e qualificações, sendo proibidas as designações discriminatórias que incitem a segregação.

Além disso, estabelece no art. 227, § 5, que: "A adoção será assistida pelo Poder Público, na forma da lei, que estabelecerá casos e condições de sua efetivação por parte dos estrangeiros".

O ECA trata de crianças e adolescentes como sujeitos de direitos, e não mais objetos como os Códigos de Menores. Dentre as inovações, essa lei passou a estabelecer o direito fundamental de crianças e adolescentes à convivência familiar e comunitária, primordialmente em sua família de origem. Todavia, na impossibilidade de manter-se nesta, reconhece também o direito da colocação em família substituta, para os casos em que não seja mais possível a 
convivência com a família natural ou extensa, e regula sobre como isso deve proceder.

Segundo Alves (2007, p. 19-20):

A família substituta deve garantir suficiente proteção à criança ou ao adolescente. Por isso, não se deferirá guarda, tutela ou adoção à pessoa que revele incompatibilidade com a natureza da medida ou não ofereça ambiente familiar adequado (art. 29 do ECA), isto é, aquele "propício a favorecer o desenvolvimento físico, mental, moral, espiritual e social de crianças e adolescentes em condições de liberdade e dignidade." (Cury, Garrido e Marçura, Estatuto da Criança e do Adolescente anotado, p. 42).

A adoção dentro do ECA consiste na mais complexa das modalidades de colocação em família substituta. De acordo com os artigos 41 desta lei art. 1.626, parágrafo único, do Código Civil, a adoção incide na atribuição da condição de filho a alguém, através de sentença.

O Código Civil (CC) "seguiu, em linhas gerais, a regulação do ECA. Assim, não resta espaço para a adoção celebrada entre partes. Só por sentença poderá constituir-se a adoção [...] (art. 1.623 e parágrafo único, do CC) (ALVES, 2007, p. 22).

Com o advento do ECA, a adoção passa a ser irrevogável, não pode ser feita por procuração (visto que determina a prévia relação pessoal entre adotante e adotado), estabelece ao adotado filiação direta com sua nova família, além de transferir o poder familiar dos pais biológicos aos adotantes. O poder familiar não pode mais ser retirado em razão da pobreza e o Estado passa a ser responsável por programas de auxílio às famílias para que estas tenham condições de se manter com seus filhos.

Para estar disponível à adoção é necessário que a criança ou adolescente tenha sido desvinculado do poder familiar, seja por morte ou pela destituição desse poder. Outras considerações importantes implantadas a partir do ECA: fica estabelecido o período de convivência entre pretendentes a pais e filhos antes da sentença, a preferência à adoção é para os brasileiros aqui domiciliados.

Os artigos 41, caput, do ECA e art.1.628 do CC estabelecem a relação de parentesco. Segundo Alves: "O primeiro dos efeitos da adoção é a atribuição da condição de filho ao adotado.
[...]A mesma condição de filho, estabelecida pela adoção, conduz à formação de parentesco entre todos os parentes do adotante." (2007, p. 26).

A adoção por estrangeiros residentes ou domiciliados fora do Brasil, também conhecida como adoção internacional, encontra-se subordinada a regras próprias. O ECA a considera excepcional (art. 31), admissível somente quando verificada a impossibilidade de adoção por brasileiros aqui domiciliados.

Segundo Veronese e Petry, as exigências feitas pelo Estatuto quanto à adoção internacional são no sentido de salvaguardar ao máximo os direitos daqueles que se submeteram a uma "perda, luto - tanto que estão à disposição de serem adotados - e, portanto, seria extremamente danoso [...] se novamente a situação de abandono, carência e maus-tratos se repetisse." (2004, p.147).

Em termos internacionais, a Convenção Relativa à Proteção das Crianças e à Cooperação em Matéria de Adoção Internacional, mais conhecida como Convenção de Haia, estabelecida em 29 de maio de 1993, em Haia, na Holanda, traçou as contiguidades para a questão da adoção internacional. Atualmente, está ratificada por diversos países, dentre eles o Brasil. Dentre os critérios estabelecidos por essa Convenção está a criação de um processo unificado e de um sistema centralizado de controle nacional.

Figueirêdo (1998, p.25) destaca várias "causas" que justificaram essa Convenção, dentre elas estão: "Abusos diversos, como busca de lucros, subornos, falsificação de registro de nascimento, coerção dos pais biológicos para concordarem com o pedido, intermediação por pessoas e entidades não habilitadas, venda e rapto de crianças".

A Convenção de Haia inspirou-se fortemente na Convenção sobre os Direitos da Criança. Entende a adoção internacional como medida excepcional, aplicada apenas quando esgotadas todas as possibilidades de viver em ambiente familiar no país de origem.

Um dos principais objetivos da Convenção está em estabelecer uma estrutura organizada entre os países que realizam a adoção internacional, com vistas a facilitar a aplicação dos dispositivos que garantam os direitos da criança, mediante a adesão obrigatória de normas e mecanismos comuns entre as partes. 
O grande intuito desse empenho internacional encontra-se no estabelecimento de mecanismos eficientes que asseverem o bem-estar do adotado, bem como uma situação jurídica invariável tanto no país de origem quanto no país adotante.

Embora se tenha avançado significativamente nas discussões a respeito da adoção internacional,

Uma grande parcela da população ainda associa a adoção a um ato caritativo e por este motivo preferem que a criança fique com uma família substituta estrangeira do que com os pais biológicos pobres. Sendo que outra parcela da população defende a permanência da criança no abrigo, em lugar do encaminhamento para a adoção internacional. A excepcionalidade da adoção internacional, bem como seu deferimento, deveria ser condicionada ao bem-estar da criança, atendendo ao superior interesse desta. (KISTEMANN, 2008, p. 19).

\section{Contextualizando a adoção internacional através da AFN/PR}

Este estudo não tem por finalidade criar rivalidade entre as modalidades de adoção nacional e internacional. Pelo contrário, o que se busca é defender o direito de crianças e adolescentes a terem uma família. Para tanto, torna-se indispensável que essa família esteja devidamente preparada para acolher bem os filhos. O processo de formação dos futuros pais representa um passo praticamente indispensável para o sucesso da adoção, seja esta nacional ou internacional.

A prática profissional da autora deste trabalho está vinculada estritamente à adoção internacional através da AFN (Ação para Famílias Novas) no Paraná, a qual representa a ONG italiana AFN (Azione per Famiglie Nuove). Portanto, o presente estudo parte da experiência prática nessa área de atuação.

A sede estadual da AFN encontra-se em Curitiba/PR. A equipe é composta pela representante nacional (pediatra e advogada), o representante estadual (advogado) e uma assistente social. Conta ainda com o apoio de uma psicóloga, que atende aos casais interessados em contratar seu serviço.

Na Itália, existe uma sede central (em Roma) e cinco sedes periféricas da AFN (Trento, Milão,
Florença, Caserta e Cosenza) que trabalham na formação dos casais antes da adoção e no acompanhamento das famílias após esta. Cada sede possui sua própria equipe de trabalho formada, basicamente, pelo responsável da sede, assistente social e psicólogo. Além dessas sedes, há mais 3 (três) pontos de referência para informações e encaminhamentos às sedes mais próximas.

Os procedimentos e estudos realizados no presente artigo estão vinculados ao universo da adoção internacional em Curitiba, a partir do trabaIho com a AFN. Isso implica considerar que existem algumas características semelhantes e outras diferentes aos demais organismos que trabalham com adoção internacional no Paraná e no Brasil.

Todos os organismos credenciados no Paraná para a adoção internacional contam com o suporte da equipe profissional da Comissão Estadual Judiciária de Adoção (CEJA/PR), a qual atua, dentre outros aspectos, na preparação direta ou indireta dos futuros adotados, no estágio de convivência entre pais e filhos (ECA, art.46, § 4) e no acompanhamento pós-adoção. Dos organismos credenciados no Paraná, apenas a AFN possui assistente social contratada para acompanhar diretamente os processos.

No que diz respeito ao processo de formação dos casais, este se inicia no organismo a partir de um primeiro encontro para informações e esclarecimentos gerais sobre os aspectos práticos do processo adotivo. Para firmar a parceria entre o organismo e os casais é necessário que primeiramente estes passem por uma avaliação da equipe técnica do Fórum de sua região.

Após a avaliação, o Fórum emite o Atestado de Idoneidade que consiste em uma certificação de que o casal é considerado apto para a adoção internacional. Em posse desse documento, do relatório psicossocial e demais documentos necessários (ECA art. 52), o casal cadastra-se no organismo que escolheu para representá-lo no processo de adoção internacional.

Depois desse cadastro, o organismo credenciado no país de origem dos adotandos e no Estado e no país de origem dos adotados, apresenta os documentos do casal para cadastramento deste junto à CEJA.

O ECA prevê no artigo 52, inciso VII que:

verificada, após estudo realizado pela Autoridade Central Estadual, a compatibilidade 
da legislação estrangeira com a nacional, além do preenchimento por parte dos postulantes à medida dos requisitos objetivos e subjetivos necessários ao seu deferimento, tanto à luz do que dispõe esta Lei como da legislação do país de acolhida, será expedido laudo de habilitação à adoção internacional [...].

Os casais permanecem, em média, dois a quatro anos esperando pela indicação do filho, desde a chegada do processo no Brasil, sem contar o tempo transcorrido na Itália para preparação da documentação. Ao longo desse período de espera pela indicação do(s) filho(s), a formação é contínua na Itália.

Essa preparação se configura como um significativo diferencial entre a formação desses casais e a de alguns casais pretendentes à adoção nacional: o acompanhamento e aprofundamento com equipe interdisciplinar, de maneira continuada, de questões pertinentes ao processo adotivo.

Os casais passam, ao longo do período de espera, por diversos encontros individuais $e$ coletivos de formação para a adoção. Nesses encontros são orientados sobre os aspectos legais, além das orientações psicológicas e do serviço social, as quais abordam diferentes temáticas.

Dentre as temáticas trabalhadas estão: a história vivenciada pelo casal que pretende adotar (o processo de luto pela esterilidade, a realização pessoal e conjugal, a reciprocidade do relacionamento); a vivência do filho adotivo como alguém que experimentou a perda das pessoas que lhe eram queridas; o relacionamento entre pais e filhos; a paternidade adotiva não é uma experiência que nasce do corpo do homem e da mulher, mas de uma reflexão pessoal e de casal; a criança real e a imaginada; os fatores que levam as crianças à adoção; as expectativas; o país de origem da criança.

Não se pode desconsiderar que em termos nacionais existem várias iniciativas voltadas à preparação dos casais para a adoção, porém, isso deve tornar-se imprescindível em todas as Comarcas. O acompanhamento especializado e continuado na preparação dos pais e dos filhos vem demonstrando, na prática com a adoção internacional, significativa diferença para a qualidade e maturidade do processo adotivo.

O período de espera que os pretendentes a pais passam não é algo de todo negativo. Esse tempo deveria ser visto como algo imensamente favorável para a maturação das motivações e o aprofundamento sobre as temáticas pertinentes ao processo adotivo, a fim de buscar torná-lo mais consciente e menos conflituoso.

O tempo de espera não é apenas um 'período de hibernação'. Os pretendentes a adoção precisam ser seguidos separada e conjuntamente por profissionais para tornar mais esclarecida e elaborada a motivação para adotar. Nesse sentido, não basta apenas um movimento incentivando as adoções nacionais, especialmente aquelas de crianças maiores, grupos de irmãos, adolescentes, crianças com deficiência, HIV positivo ou outra doença de considerável gravidade. Esses sujeitos constituem um grupo de pouco interesse para as adoções nacionais.

Há muito que se fazer no sentido de preparar os pais e filhos para constituírem-se como família, visto que se trata de um vínculo indissolúvel (ECA art. 39, § 1ㅇ). Portanto, constitui-se imprescindível a defesa da formação iniciada desde o começo do processo e de maneira mediata, além do acompanhamento bastante próximo no estágio de convivência e após a adoção.

Outro aspecto muito importante a ser considerado na família que pretende adotar é a sua família alargada. É importante considerar se o filho será bem acolhido no novo meio.

Além da formação dos pretendentes a pais, há que se considerar também a relevância da preparação dos futuros filhos à nova vida em família. É aconselhável que tal preparação aconteça algum tempo antes do encontro entre pais e filhos, a fim de que os elementos que emergem nesse período sejam devidamente elaborados.

\section{A naturalização da ilegalidade}

Os erros cometidos na leitura de determinadas realidades podem acarretar na aplicação da lei ou de procedimentos de maneira equivocada. Quando esse processo tende a se repetir de maneira continuada, situações particulares passam a ser "compactadas" em um único contexto a partir do qual se "rotulam" a aplicação das mesmas medidas para a "solução" de todos os casos. A esse processo deu-se o nome, neste trabalho, de naturalização da ilegalidade.

A Constituição Federal de 1988 e o ECA asseguram que cabe à família, à sociedade $\mathrm{e}$ 
ao Estado (nas três esferas de Poder) o dever de cuidar e proteger as crianças e adolescentes. Uma vez afastados da família e institucionalizados, esses sujeitos começam a fazer parte de uma realidade que pode ser denominada como um "funil da violação" dos direitos.

A extremidade que conduz ao acolhimento institucional costuma ser ampla e de acesso relativamente fácil. Aconduta mais justa, ao se deflagrar crianças ou adolescentes aparentemente em situação de risco, deveria ser a de procurar a família e verificar o que pode ser feito entre os familiares, bem como os encaminhamentos a programas efetivos de auxílio à família. Contudo, muitas vezes ocorre o inverso: primeiramente a institucionalização para depois se analisar a situação.

Nas entidades de acolhimento institucional por vezes se observam extremos que vão desde o sentimento de posse pelas crianças/adolescentes até o puro descaso frente à existência deles. Soma-se a isso a carência de profissionais habilitados para a devida preparação à adoção, além de entendimentos equivocados que consideram como preparação: informar à criança que ter família é "possuir pais que dão de tudo".

Entre os profissionais envolvidos nessa realidade há os que estão frustrados pelo baixo salário, pelas condições de trabalho ou propriamente desatualizados. $\mathrm{E}$ há aqueles envolvidos com a causa, mas sem o devido apoio da rede. A preparação dos profissionais que atuam nas instituições, prefeituras ou mesmo fóruns vem mostrando-se imprescindível: a constância entre omissão e distorção sobre as informações das crianças e adolescentes vem se tornando cada vez mais frequente e isso é algo muito grave.

Quando a devida preparação é feita aos pais e aos filhos, o estágio de convivência entre eles tende a possuir menores perturbações. $O$ estágio de convivência (ECA art. 46) diz respeito ao período em que a futura família passa a viver junto para se conhecerem e começarem a estabelecer os vínculos afetivos, precede a sentença de adoção para atestar se pais e filhos convivem bem juntos.

Vargas chama a atenção para o fato de que o acompanhamento profissional fornecido aos pais ajuda-lhes no sentimento de carência ou até impotência diante de certas situações, donde a informação recebida se faz muito "necessária para lidarem adequadamente com as situações específicas surgidas". E assinala, ainda, "a importância de reuniões, grupos de pais adotivos para a troca de experiências." (1998, p.76).

Um dos fatores mais importantes para a carência de trabalhos continuados voltados à formação dos pretendentes à adoção e na devida preparação das crianças encontra-se no número reduzido ou na ausência de profissionais trabaIhando nos Fóruns das Comarcas.

Outra problemática pertinente aos profissionais (dos Fóruns, Prefeituras ou Instituições) diz respeito ao considerável tempo de atuação na área, mas sem a devida motivação ou incentivo para que possam renovar seus conhecimentos. Diante disso, acabam desenvolvendo sua prática profissional de maneira pontual e pouco reflexiva. Um dos grandes riscos disso é que a rotina pode tender a um comportamento de senso comum que não reflete sobre os fatos e pode fortalecer a 'naturalização da ilegalidade'.

Os profissionais precisam receber apoio, seja da instituição à qual estão vinculados ou através de parcerias. Constitui-se como fundamental e imprescindível que

[...] os profissionais envolvidos com o atendimento a crianças e adolescentes precisam estar aptos e preparados para os desafios impostos pelo trabalho, sob o risco de não conseguirem acompanhar as constantes mudanças que suas práticas demandam. (RIZZINI, 2006, p. 94-95).

Nesse sentido, um profissional desatualizado pode, mesmo que 'involuntariamente', estar violando tanto as legislações específicas de sua prática profissional quanto a própria Constituição Federal de 1988 e outras leis.

$\mathrm{Na}$ sociedade existe uma cultura preconceituosa sobre as famílias pobres, culpabilizando-as pela situação em que se encontram versus uma passividade na qual o interesse maior está em "ocultar o problema", ao invés de resolvê-lo.

No poder público, nos conselhos de direito e em outras instâncias vinculadas à defesa e execução dos direitos da criança e adolescente, os interesses individuais e de algumas categorias ainda prevalecem sobre os coletivos. Tal fator permite a existência de ações descontinuadas e mal planejadas que prejudicam consideravelmente a população, em especial modo, às crianças e adolescentes. 
No poder judiciário, os extremos da distorção da lei, aplicada visando a redução do tempo de institucionalização, vão da destituição familiar "fundamentada" exclusivamente na pobreza (ECA, art. 23 e parágrafo único), ao excesso de tentativas de adoção. Há casos em que as tentativas de colocação em família substituta, justificadas pela intenção de acelerar o processo, possuem um espaço de tempo tão curto entre uma tentativa e outra que o dano causado à criança é maior do se ela tivesse permanecido o tempo todo institucionalizada.

Há também outros problemas, que se pretende solucionar com as alterações da lei $n^{\circ}$. 12.010, como a excessiva lentidão nos processos que leva os sujeitos a permanecerem por mais de cinco anos institucionalizados, sem saber se retornarão para a família de origem ou não.

Em virtude dessas lacunas existentes no sistema de garantia de direitos, o acolhimento institucional, que deveria ser uma medida emergencial e temporária, encontra vários entraves. Tanto isolados como conjuntamente, vão violando os direitos dos sujeitos envolvidos e, consequentemente, prejudicando o seu pleno desenvolvimento.

Destarte, a desinstitucionalização, seja por retorno à família ou por outros meios como a adoção, torna-se muito mais complexa. Portanto, dentro do "funil da violação" dos direitos, a extremidade mais estreita (do direito à convivência familiar e comunitária) é justamente aquela que depende de uma série de fatores e operadores. Para ocorrer uma mudança nessa situação constituem-se necessárias uma série de medidas para os diversos mecanismos envolvidos.

Uma vez decretada a destituição do poder familiar, a desinstitucionalização dar-se-á através de guarda, tutela ou adoção. No entanto, ainda assim o tempo de permanência nas entidades de acolhimento institucional vem sendo prolongado. Soma-se a isso o fato de que algumas fundamentações de destituição parecem não acompanhar ao que prevê a lei.

O artigo 23 do ECA afirma que a "falta ou a carência de recursos materiais não constitui motivo suficiente para a perda ou a suspensão do poder familiar". E o parágrafo único do mesmo artigo reafirma tal ideia, complementando ainda que: "Não existindo outro motivo que por si só autorize a decretação da medida, a criança ou o adolescente será mantido em sua família de ori- gem, a qual deverá obrigatoriamente ser incluída em programas oficiais de auxílio".

Há que se considerar também que a naturalização da ilegalidade configura-se como fruto de uma leitura pontual e distorcida acerca da sociedade brasileira. Em especial modo, no que diz respeito às famílias empobrecidas e a relação destas com o "abandono" de seus filhos.

A situação de pobreza intensifica a falta de perspectiva quanto a um projeto de vida com qualidade, pois estabelece uma luta desigual pela mera sobrevivência. Segundo Kaloustian e Ferrari (1994), por trás das crianças e adolescentes excluídos do acesso à educação e moradia com qualidade, inseridos no trabalho precoce e em situação de risco, encontram-se famílias desassistidas ou não atingidas pelas políticas públicas.

"Nesse sentido, a consequência desse descaso público com as famílias pobres no Brasil torna-se uma questão muito mais ampla do que se imagina, orfaniza-se a infância pobre e destitui suas famílias do poder familiar", visto que "a família dificilmente consegue se recompor financeiramente para reaver a posse dos filhos." (SILVA, 2006, p.29).

Assim sendo, a medida de destituição do poder familiar diversas vezes ocorre como consequência (mesmo que imperceptível socialmente) das desigualdades sociais, culturais e políticas. Pois, o não acesso aos direitos fundamentais pode estimular consideravelmente a precariedade nas condições de vida dos membros das famílias.

Destarte, a situação de pobreza acarreta direta e/ou indiretamente a violação de direitos nas suas diversas formas. Assim, a pessoa que se encontra em situação de vulnerabilidade dificilmente consegue, por si só, encontrar meios de inserir-se na garantia dos direitos fundamentais, sendo que muitas vezes sequer conhece a existência destes.

Kaloustian e Ferrari (1994, p. 63) evidenciam que:

[...] a questão da pobreza deve ser examinada do ponto de vista estrutural, relacionada ao modelo de desenvolvimento que privilegia a concentração de riqueza e é determinada, em grande parte, por políticas de ajuste internacionalmente impostas e que acarretam significativos cortes orçamentários na área social. 
A situação de pobreza permeia o ambiente familiar influenciando na vida de seus membros. Dessa forma, os fatores políticos e econômicos rebatem na organização familiar, trazendo sérias consequências à socialização da família. Portanto, ao se falar de crianças e adolescentes que passaram por uma situação de abandono, é importante ressaltar a relevância da interferência que a situação de pobreza aplica sobre isso.

A pobreza não é por si só a "culpada" por tudo, se é que nominar culpados vá solucionar uma problemática tão ampla e complexa como a questão do abandono, da violência familiar e de outros fatores que desencadeiam a separação de pais e filhos.

\section{A crítica à separação de irmãos: uma reali- dade complexa}

A temática sobre a separação de irmãos devido à adoção, embora mereça por si só um estudo específico a respeito, vem crescendo em discussões, especialmente no âmbito acadêmico. Quando se fala em adoção internacional, então, a questão se torna ainda mais polêmica e criticada.

Sustenta-se um discurso sobre a lacuna causada na vida dos irmãos pelo fato de uns irem para adoção e outros não.

O que muitas vezes não se evidencia é que o "lobo-mau" talvez não seja propriamente a escolha pela adoção de uns (é óbvio que não se pode agir de má-fé apenas por acreditar que a criança estará melhor em outra família, há muitos fatores a serem considerados e preparados quando houver a separação), mas, existe uma significativa sequência de ações de órgãos e profissionais que estão envolvidos nessa decisão e também precisam ser trazidas nas discussões, para enriquecer as reflexões.

O que se passa despercebido muitas vezes é o fato de que, ao se tomar a decisão sobre a separação de irmãos, isso por si só já aponta um sinal de que há muitas falhas no sistema de garantia de direitos.

Um considerável número de adolescentes que se encontram acolhidos chegaram à instituição de acolhimento ainda crianças e enfrentam uma realidade de prolongado afastamento do convívio familiar. Além disso, nem sempre ao serem desligados por completarem 18 anos, ou mesmo antes disso, recebem a devida preparação para as realidades externas à instituição de acolhimento.

Vem se mostrando um caminho mais fácil criticar a separação entre crianças e adolescentes, irmãos, devido à adoção apenas dos mais novos, sobretudo pela quebra dos vínculos que muitas vezes ocorre.

Todavia, há que se considerar também se esse irmão mais velho, ao completar 18 anos, terá condições de assumir a responsabilidade pelos mais novos, porque não se pode condenar os irmãos mais novos a viverem prolongadamente na instituição à espera do momento em que o irmão mais velho consiga ser capaz de assumi-los.

Se esse jovem não recebeu uma boa formação profissional, além de possuir dificuldades para se sustentar, provavelmente não conseguirá sustentar seus irmãos, se é que deseja fazê-lo. Então, como condenar os irmãos a permanecerem acolhidos institucionalmente? Se a colocação em família substituta pode ser cruel para os irmãos, em especial ao irmão que não é adotado, do mesmo modo, obrigar todos a permanecerem acolhidos institucionalmente por ausência de casais disponíveis para adotar todos também pode ser cruel.

Para além de se discutir os benefícios e malefícios da separação, não se pode perder de vista a atual ausência de políticas públicas eficientes para responder devidamente à problemática, principalmente na prevenção. Há que se investir muito no fortalecimento dos vínculos, em políticas cautelosamente planejadas para melhorar a qualidade de vida das famílias de origem, a fim de prevenir as situações de vulnerabilidade e risco, bem como proteger e acompanhar aquelas que já se encontram em tais situações.

Indubitavelmente não se pode deixar de pensar o que se pretende para o país e à sociedade nas próximas gerações. Todavia, há um emaranhado de situações que, na atualidade, ainda emperram o bom andamento das adoções daqueles sujeitos em que a procura pelos pais é menor. Enquanto isso, não se pode esquecer que eles continuam a crescer afastados do direito à família.

Não se faz necessário divagar muito, basta refletir sobre quantas e quais são as pessoas ou famílias nacionais que atualmente se encon- 
tram disponíveis e preparadas para acolher, por exemplo, um grupo de quatro ou seis irmãos em adoção. $O$ fator financeiro influencia consideravelmente, mas também existe uma carência de programas que auxiliem de fato essas famílias.

Do mesmo modo, pensar em um acréscimo de seis pessoas em uma família, praticamente "do dia para a noite", sendo que esses sujeitos já possuem uma história de vida muitas vezes marcada pela violação de direitos; uma personalidade, se não formada, pelo menos forjada por certos valores adquiridos; cada um desses sujeitos tem suas características e necessidades próprias e diferenciadas.

Além disso, ao se pensar em seis irmãos, é bem provável que pelo menos um ou dois deles sejam adolescentes, portanto, possuem também uma capacidade de questionar, desafiar, desacreditar e "pôr à prova" os adultos de tal modo que seja capaz de interferir nos relacionamentos, especialmente na fase de estabelecimento da confiança para fortalecimento dos vínculos afetivos.

Destarte, se faz necessário pensar em alternativas para a manutenção dos vínculos fraternais, porém, a adoção é algo sério e não pode ser tratada superficialmente apenas sobre certos aspectos. Do mesmo modo como a separação dos irmãos, principalmente nos casos em que uns permanecem acolhidos institucionalmente e outros são adotados, pode acarretar sofrimentos entre todos, assim também, manter todos os irmãos abrigados simplesmente para evitar separá-los é uma violência e privação de direitos.

Há que se pensar, a longo prazo, e planejar alternativas para mudar a realidade atual. Também é necessário investir sempre mais na devida formação dos pretendentes a pais adotivos. Mas, não se pode deixar de fazer no presente por aqueles que já se encontram institucionalizados e sem muitas alternativas.

Embora não se possa generalizar uma "solução" para todos os casos, torna-se imprescindível destacar que um acompanhamento continuado dos irmãos que vão e daqueles que ficam (principalmente quando já mantinham contato no Brasil) vem mostrando resultados significativamente importantes constatados pela AFN.

Outra crítica relevante feita à separação dos irmãos diz respeito à divisão destes em duas famílias. Há que se considerar que na adoção internacional existem casos em que uma única família adota um grupo de irmãos sem dividilos. Porém, isso vai depender principalmente da situação econômica do casal e da realidade cultural do país acolhedor.

Todavia, há também restrições estabelecidas por mecanismos legalizadores da adoção em alguns países, nas quais se restringem ou inviabilizam a adoção de mais do que dois ou três filhos, dentre outros fatores. Além de todos os desafios que o processo de vinculação entre pais e filhos acarreta, no caso da adoção internacional também está presente a diversidade de línguas e culturas.

Tal diversidade pode se tornar um agravante nas primeiras dificuldades que emergem no início da convivência, especialmente quando nenhum dos pais conhece ao menos algumas palavras em português. Entretanto, é importante manter os 'pés no chão' e evitar certos romantismos que ofusquem a apreensão concreta do fato.

Tornar-se "de um dia para o outro" pai/mãe de crianças crescidas e/ou adolescentes e/ou com implicações na saúde, em outro país, longe de familiares, amigos, trabalho, pessoas que falam a mesma língua e demais componentes do cotidiano dos pais e, "de repente", passar a conviver com "estranhos" dentro e fora de casa; ter a rotina completamente modificada para se dedicar exclusivamente aos filhos que, não obstante se conhecessem algumas informações a respeito, ainda são desconhecidos e se encontram inseguros.

Some-se às dificuldades iniciais, pertinentes ao processo de adaptação/vinculação, o fato de haver um grande número de filhos convivendo em um mesmo espaço, cada um com seu próprio modo de tentar compreender a situação e fazer parte dela: a confusão parece ser quase inevitável.

Os futuros filhos, por vezes, já vivenciaram situações de abandono, negligência, morte, ou mesmo o afastamento dos pais biológicos "justificado" pela pobreza, e tantos outros fatores que "fundamentam" a destituição do poder familiar.

Essas experiências precedentes constituem-se de singular relevância aos obstáculos iniciais que a convivência com uma nova família apresenta, além de ampliarem bastante o grau de dificuldade nos casos em que os filhos não foram acompanhados e preparados adequadamente para a adoção.

Torna-se necessário considerar que a futura harmonia familiar passa pela construção 
saudável dos vínculos afetivos, portanto, a "solução" para a melhor qualidade de vida dos filhos pode não estar relacionada apenas ao fato de não dividir os irmãos, visto que existem outras variáveis a serem consideradas.

Não se pretende, neste estudo, fazer qualquer tipo de apologia à separação descriteriosa dos irmãos. Pelo contrário, o que se pretende é desvelar, trazer à tona, outros aspectos também relevantes, porém, que costumam ser deixados à parte quando se discutem temáticas como $\mathrm{a}$ separação de grupos de irmãos.

A decisão sobre a separação ou não dos irmãos não é uma escolha a ser feita por qualquer pessoa. Ela requer acompanhamento de profissional (is) da área e precisa ser analisada concretamente, sem "amadorismos".

\section{O acompanhamento dos adotados internacionalmente, através da AFN/PR}

O artigo 52, § 10, do ECA assegura que a "Autoridade Central Federal Brasileira poderá, a qualquer momento, solicitar informações sobre a situação das crianças e adolescentes adotados". O art. 47, § 8 dispõe sobre o arquivamento das informações dos processos.

A elaboração ou apresentação dos relatórios requeridos pelos juízes são de responsabilidade do organismo credenciado, o qual os apresenta na língua original em que foram redigidos e traduzidos para o português, para o juiz da Comarca de origem da criança, para a CEJA e para a Autoridade Central em Brasília.

Segundo o art. 52, §4, cabe aos organismos credenciados:

IV - apresentar à Autoridade Central Federal Brasileira, a cada ano, relatório geral das atividades desenvolvidas, bem como relatórios de acompanhamento das adoções internacionais efetuadas no período, cuja cópia será encaminhada ao Departamento de Polícia Federal;

V - enviar relatório pós-adotivo semestral para a Autoridade Central Estadual, com cópia para a Autoridade Central Federal Brasileira, pelo período mínimo de 2 (dois) anos. O envio do relatório será mantido até a juntada de cópia autenticada do registro civil, estabelecendo a cidadania do país de acolhida para o adotado
Além dos relatórios pós-adotivos aos quais a AFN/PR tem acesso, essa equipe também costuma trocar e-mails com as famílias, telefonar e receber telefonemas, além de conversar através de um programa de computador chamado Skype.

Em média uma vez por ano o representante estadual da AFN participa, também, na Itália, de encontros de formação para casais interessados em adoção e famílias que já adotaram. Além dos encontros, realizam-se ainda algumas visitas às casas de famílias adotantes, ou mesmo passeios. Além da presença do representante, há ocasiões em que outros convidados como juízes, equipe técnica do Fórum, equipe técnica da CEJA/PR e membros componentes da CEJA/ PR participam desses eventos.

Nessas ocasiões é possível conhecer os candidatos a pais pessoalmente, além de conviver um pouco com várias das famílias que passaram pela adoção internacional no Brasil e saber como estão no momento.

Através dessas experiências é que o acompanhamento da AFN/PR costuma ser desenvolvido. Isso proporciona respaldo e segurança para confiar no trabalho que é realizado, visto que permite ter acesso aos "frutos" daquilo que foi seguido no Brasil.

Há também cartinhas que as crianças e adolescentes escrevem e entregam ao representante estadual da AFN no Paraná. Essas cartas manifestam expressões espontâneas desses sujeitos, que passaram pela adoção e que se encontram no país de acolhida (Itália) há algum tempo.

Em virtude dos relatórios pós-adotivos serem tidos como segredo de justiça, optou-se neste artigo por apresentar algumas das cartas recebidas. Neste trabalho foram escolhidas as cartas escritas por adolescentes, devido ao fato de que eles já conseguem assimilar e elaborar melhor os eventos vivenciados, além de expressar suas ideias geralmente de forma escrita, portanto, não há necessidade de interpretação de figuras.

Nem todos os adotados escrevem cartinhas, então, o critério de seleção para este artigo foram as cartas escritas pelos adotados através da AFN/PR. Eles atualmente se encontram na fase da adolescência e escreveram, espontaneamente, algo a respeito de sua experiência. 
As cartas foram recebidas em mãos, em momentos diferentes, escritas por sujeitos que já se encontram há mais de três anos na Itália e habitam em diferentes regiões daquele país. Embora escritas em anos diferentes, todas as cartas foram entregues ao representante estadual da AFN no PR em ocasião de sua visita às famílias na Itália.

O primeiro caso diz respeito à irmã mais velha de um grupo de três irmãs. Trata-se de uma adolescente que atualmente está com quinze anos. Essa carta foi escrita e lida pela adolescente durante um encontro sobre adoção internacional, no qual estavam presentes juízes, profissionais da área, pais adotivos e candidatos a pais.

Eu me chamo Maria ${ }^{1}$ e tenho 13 anos, nasci no Brasil e vivo aqui na Itália desde 2006. Nos meus primeiros dez anos de vida passei muito tempo, mesmo se em momentos diversos, em abrigo. Na última vez em que voltei (ao abrigo) foi em 2005, a minha vida estava muito diferente: eu não tinha regras, fazia tudo aquilo que queria e frequentemente não dava ouvidos àquilo que me diziam. Às vezes fantasiava que tinha uma nova família, porém, naquele tempo eu jamais teria aceitado esta ideia porque pensava em retornar aos meus verdadeiros pais e não queria deixar os meus amigos, embora soubesse que eles mais cedo ou mais tarde partiriam. E um dia chegou aquilo que no momento eu não queria: tudo teve início em 2006, quando me disseram que eu teria uma nova família. Minha primeira reação foi negativa porque de certa forma me sentia feliz também no abrigo. Depois, porém, mudei de ideia porque percebi que tinha a possibilidade de melhorar a minha vida e ter uma família verdadeira, assim, comuniquei a notícia a todos os meus amigos e colegas de escola... Chegou o grande dia, em que tive que dizer adeus ao meu passado e à minha terra... estava para ter uma nova vida, uma nova família e estava para descobrir uma nação e uma língua para mim desconhecidas. Quando conheci meus pais adotivos, meu coração subiu à boca e fiquei feliz. Imediatamente me dei conta de que eles estavam emocionados: eu deduzi pelos olhares e pe- los gestos. Conosco estava Sandro², o qual traduzia tudo o que dizíamos. Passaram-se alguns dias e eu me dava conta de que nossa vida estava mudando. Chegou o dia mais importante para mim e para meus pais, era a data da sentença final, com a qual me tornaria filha para todos os efeitos. Aquele dia eu estava muito tensa e sentia dentro de mim uma voz que me encoraja a esta nova aventura. Chegou o dia da partida para a Itália, para a minha nova casa. Eu estava um pouco melancólica e não sabia se conseguiria afrontar aquela nova realidade. A viagem foi muito movimentada para meus pais, mas para mim foi muito bela porque pude viajar e conhecer uma nova terra e uma nova cultura. Meus novos pais já haviam entrado no meu coração desde a primeira vez que os vi, eu estava feliz e começava a gostar deles. Passaram-se alguns meses e eu estava serena e tranquila. Meus pais eram sempre cuidadosos e amáveis e eu nunca lhes pedi algo a mais porque tudo o que tinha me deixava feliz. Eu me dava conta de que cada vez mais a vida na minha nova família era muito bela. Algumas vezes me vinham dúvidas e um pouco de melancolia, porém, com a ajuda dos meus pais eu as superava. Assim, chegou o primeiro dia de aula, estava feliz e emocionada porque estava para conhecer os meus novos colegas. Acolheram-me muito bem e fizeram eu me integrar facilmente. Fiz muitas amizades e no ambiente social sempre estive bem. Também graças aos meus pais, conheci lugares muito bonitos, na província de Cosenza e na Calábria. Hoje frequento o segundo ano do ensino médio e estou indo muito bem, algumas vezes encontro um pouco de dificuldade porque aqui na Itália estudei apenas a partir da quinta série. Na escola procuro dar sempre o melhor de mim e penso que consigo graças ao meu empenho cotidiano, ao encorajamento de todos os professores, sobretudo de minha professora de italiano, e aos meus pais que me seguem passo a passo. Hoje sou a mais feliz do mundo porque tenho tudo aquilo que uma moça como eu pode desejar da vida: tenho pais esplêndidos, muitos amigos e, principalmente, a serenidade. Devo agradecer também aos avós e tios que acolheram a mim e minhas irmãs Joana e Tereza com tanto

\footnotetext{
1 Os nomes dos adolescentes e familiares foram alterados e os dados pessoais ocultados para não identificar a pessoa que escreveu a carta.
}

\footnotetext{
${ }^{2}$ Sandro Melo é o representante estadual do organismo AFN no Paraná. Todas as referências direcionadas ao Sandro referem-se à mesma pessoa.
} 
amor. Acredito que as pessoas que escolhem adotar uma criança a salvam do sofrimento, da infelicidade, da pobreza e de uma vida não adequada a uma criança, uma vida sem festas de aniversário, sem presentes de Natal, sem beijos, abraços e carícias. Quem adota uma criança lhe doa uma vida melhor, um futuro, amor, felicidade e um sorriso. Espero muito que várias pessoas escutem esta mensagem e a transmitam à sua volta a tantos outros que talvez não tenham ideia do que é a vida de uma criança pobre, infeliz e, sobretudo, sem uma família.

Agradeço a todos por tudo aquilo que fizeram até agora e principalmente por aquilo que espero que farão no futuro.

A segunda carta apresentada foi escrita pela irmã do meio da adolescente que escreveu a carta acima, aqui chamada de Joana. Trata-se de uma adolescente que está com quatorze anos.

Querido Sandro,

Senti muito a tua falta, todas as noites penso em você, mas hoje é um dia especial para mim, mamãe, papai, Maria e Tereza. Eu estou muito bem com mamãe e papai, eles estão muito contentes por ter nos adotado.

Também na escola vou indo bem, a professora de italiano aumentou minha nota, quase todas as crianças da escola gostam muito de mim.

Daqui a pouco me tornarei uma atriz e cantora, porque mamãe e papai quiseram que eu fizesse um curso de canto e de teatro na escola.

Mamãe e papai me compraram o vestido para o carnaval e escolhemos juntos o de fada.

A carta a seguir também foi escrita por Joana. Trata-se de uma cartinha de Natal, destinada a Jesus Menino e encaminhada pelos pais da adolescente para a AFN/PR.

Carta a Jesus Menino.

Querido Jesus Menino, te escrevo esta carta para te pedir três grande presentes, não apenas para mim, mas para todo o mundo. O primeiro desejo que queria que você concedesse é o de parar com todas as guerras, porque há tantas pessoas que sofrem e que morrem por causa das guerras. Quando assisto o telejornal e escuto que falam das pessoas que sofrem me vem uma forte dor no fundo do coração. O segundo pedido que te peço é que não tenham mais pessoas pobres, que não têm nada para comer, para beber e que morrem. Eu decidi que quando crescer quero ter muitos trabalhos para me tornar rica, assim poderei dar a maior parte daquilo que tenho para os pobres que não têm nada, sobretudo para as crianças, que não têm nenhuma culpa.

Querido Jesus, minha última prece que te faço é a de ajudar a todas as crianças que vivem na rua ou mesmo nos abrigos, assim como eu vivi no Brasil até o ano passado. No abrigo onde eu estava haviam pessoas ruins que não nos davam aquilo que as pessoas que vinham nos visitar nos doavam, como roupas, coisas para comer, brinquedos e coisas para a escola. Peço, Jesus Menino, que todas as crianças tenham uma família e que tenham tudo aquilo que eu tenho agora, coisas para comer, roupas e brinquedos e, sobretudo, meus pais que me amam.

A próxima carta foi escrita por João, que está atualmente com treze anos. A carta foi escrita em virtude da visita realizada à casa da família dele.

Caro Sandro, uma vez que já faz tempo que não te escrevo, desejo te contar sobre a minha vida que se passou nestes últimos anos na Itália. Primeiramente, quero te agradecer pelo que fez, foi de grande ajuda, graças a você a história começou. Quando cheguei à Itália me parecia estranho, mesmo porque eu nunca havia estado num país onde as pessoas falam uma língua diferente da minha. Fui acolhido como se viessem buscar à porta alguém muito, mas muito importante, a única coisa que não faltava ali era a felicidade, o amor e os presentes. Quando vi a minha casa fiquei estupefato e, abrindo a porta do meu quarto disse a mim mesmo: "Mas tudo isso é meu?!!"

Os primeiros dias foram um pouco estranhos porque precisava me habituar, comecei a fazer novas amizades, novas simpatias, novos momentos de felicidade. Depois iniciei a escola, minha mãe estava bastante preocupada, mas quando terminei a primeira aula e the disse que gostei, então ela se tranquilizou. Os meses passavam da maneira que pude levar até quando pensei nas médias, dali a pouco chegariam e estava me perguntando se era capaz de superálas. O primeiro ano do ensino médio foi muito bem, mesmo tendo mudado um pouco as notas altas habituais. O segundo ano foi 
realmente bom, em virtude também de eu ter me tornado um pouco mais aberto, já não me envergonho mais tanto como nos primeiros anos. Chegamos em 2010 e você finalmente veio nos visitar, depois de tanto tempo. Eu me lembro dos belos passeios na chácara e também de quando pescamos. Os meses no Brasil se tornaram inesquecíveis. Agora estamos aqui juntos contigo e só de pensar que amanhã de manhã partirá me entristece. Ainda voltaremos a nos rever, quem sabe... talvez irei te encontrar...

Um imenso abraço.

A seguir está a transcrição de um cartão, escrito por José, um adolescente que está, atualmente, com treze anos. Ele foi adotado junto com sua irmã mais velha, Ester, de dezesseis anos:

Tio Sandro, te agradeço muito por tudo aquilo que fez. Você encontrou uma família para nós, a qual cuida de mim e de minha irmã, e mamãe e papai nos ajudam e fazem muitas coisas por nós.

Já faz dois anos e me adaptei à família, nós nos divertimos muito com eles e estamos muito felizes. Eu e minha irmã Ester te agradecemos de coração e gostamos muito de nossa família italiana.

\section{Tchau tio Sandro.} carta:

O mesmo adolescente escreveu, em outra

Com muito afeto, de José para o tio Sandro. Bom trabalho aqui na Itália para todos os dias, os amigos não se deixam até a morte, obrigada por tudo o que fez por todos nós tio Sandro, eu e Ester estamos muito felizes.

A próxima carta diz respeito a uma redação solicitada pela professora sobre um tema livre. Devido ao fato de a redação estar escrita direcionada ao representante estadual da AFN/PR, os pais a encaminharam a esse organismo. Foi escrita por Sabrina, uma adolescente que tem doze anos atualmente e foi adotada juntamente com seu irmão mais velho, Augusto, que está com quinze anos.

CARTA PARA SANDRO

QUERIDO TIO SANDRO,

Agradeço-te por ter me feito encontrar mamãe Gabriella e papai Antonio, embora sinta falta de algumas coisas. E porque me fez encontrar as minhas professoras e Elena, os meus amigos e avós, tia Anna, a irmã da mamãe. Este presente eu pedia há muito tempo. Querido tio, os meus amigos me pedem para falar em português, mas não consigo. Aqui na Itália eu me divirto, gosto de tudo, você me fez encontrar o amor, o coração e o sonho se tornou realidade para mim. Pedirei ao Papai Noel um Nintendo Dez com jogos, mas te agradeço verdadeiramente muito pelo presente mais importante que não esquecerei jamais. O primeiro dia em que eu e Augusto encontramos mamãe e papai me emocionei demais, comecei a chorar, você me presenteou com a minha vida, que é a minha família, gosto muito de você e penso frequentemente em você pelo presente que me deu. Quando crescer te darei um presente grandíssimo que não se esquecerá por toda a vida.

A intenção maior ao apresentar estas cartas está em propiciar maior visibilidade e conhecimento a respeito da situação de alguns adotados, expressa espontaneamente por eles mesmos. Procurou-se manter fidelidade às informações, ocultando-se apenas dados que pudessem vir a identificar, de algum modo, os autores das cartas.

Trata-se de um modo singelo de se expressarem, porém, pleno de sentimentos e manifestações importantes. Tais manifestações conduzem à reflexão acerca da vivência precedente desses sujeitos e a capacidade de superação apresentada.

É praticamente incontestável queas crianças e adolescentes adotados internacionalmente passaram por alguma forma de violação dos direitos. O ECA apresenta-se justo ao defender a adoção internacional apenas como último recurso, pois temos responsabilidade enquanto família, sociedade e Estado diante de nossas crianças e adolescentes.

Contudo, há que se reconhecer que, para os casos aplicáveis ao Estatuto, esse último recurso se manifesta válido e, portanto, reconhecível, pois garante a condição de filhos àqueles que de algum modo a haviam perdido, além de assegurar o direito a uma nova convivência familiar e comunitária aos que estiveram temporariamente excluídos da plena efetivação desse direito. 


\section{Considerações Finais}

O direito à convivência familiar e comunitária, não obstante esteja previsto em lei, precisa ser garantido efetivamente. A adoção internacional está inserida nesse contexto e, conforme a previsão legal, se apresenta como último recurso à efetivação do direito supra citado.

Para tanto, assim como na adoção nacional, há que ser devidamente acompanhada, visando possibilitar aos pretendentes a pais e a filhos a efetiva e adequada formação e vinculação, bem como acompanhá-los após a sentença de adoção, fornecendo-lhes o devido suporte.

As legislações nacionais e internacionais avançaram significativamente no sentido de assegurar a garantia de direitos. Mas ainda há muito o que ser construído e discutido pelos diversos setores que atuam no desenvolvimento da prática de adoção, visando concretizá-la de acordo com a previsão legal e, assim, possibilitar aos pais e filhos, constituídos a partir da adoção, a oportunidade de compor de fato uma família.

Este estudo teve como pretensão refletir a respeito da efetividade da adoção internacional e que esta não se constitui como uma prática de tráfico de crianças para o exterior. Ao contrário, existe para evitar tais práticas, que ocorrem através da regulamentação dos procedimentos e do acompanhamento continuado.

A realidade brasileira, tal qual se apresenta, ainda não consegue responder devidamente a todos os casos de crianças e adolescentes disponíveis à adoção. Um dos diferenciais importantes encontrados nos estrangeiros interessados em adotar no Brasil está no interesse pelo filho de maneira superior às suas próprias expectativas, o que conduz à vinculação e aceitação recíproca. Esse se configura como um dos fatores mais importantes na adoção e precisa ser incorporado de maneira mais efetiva também pelos brasileiros.

Destarte, a partir da construção deste estudo, se entende como necessária e se recomenda a existência cada vez maior de um esforço do Estado enquanto sociedade política, sociedade civil e atuação do judiciário na reflexão dessa realidade, bem como na contínua busca de alternativas que venham a responder devidamente nos vários segmentos do direito a convivência familiar e comunitária.

\section{Referências}

ALVES, Roberto Barbosa. Direito da Infância e da Juventude. 2. ed. atual. São Paulo: Saraiva, 2007.

AMARAL E SILVA, Antonio Fernando. Comentários do debatedor. In: SIMONETTI, Cecília; BLECHER, Margaret; MENDEZ, Emílio Garcia. Do avesso ao direito. São Paulo: Malheiros, 1994.

AMIM, Isabela Dias; MENANDRO, Paulo Rogério Meira. Preferências por Características do Futuro Filho Adotivo Manifestadas por Pretendentes à Adoção. Interação em Psicologia. Curitiba, v. 11, p. 241-252, 2007. Disponível em: <http://ojs.c3sl.ufpr.br/ ojs2/index.php/ psicologia/article/view/7653/ 8145>. Acesso em: 27 set. 2010.

BRASIL. Constituição (1988). Constituição da República Federativa do Brasil: texto constitucional promulgado em 5 de outubro de 1988, com as alterações adotadas pelas Emendas Constitucionais $n^{\circ} .1 / 92$ a 53/2006 e pelas Emendas Constitucionais de Revisão n. 1 a 6/94. Brasília, Senado Federal, Subsecretaria de Edições Técnicas, 2007.

CÓDIGO CIVIL. Disponível em: <http://www. planalto. gov.br/ccivil_03/Leis/2002/ L10406.htm>. Acesso em: 27 set. 2010 .

CONSELHO FEDERAL DE SERVIÇO SOCIAL. 0 estudo social em perícias, laudos e pareceres técnicos: contribuição ao debate no judiciário, no penitenciário e na previdência social. São Paulo: Cortez, 2005.

CONVENÇÃO AMERICANA SOBRE OS DIREITOS HUMANOS (1969). Disponível em: <http:// www. pge.sp.gov.br/centrodeestudos/bibliotecavirtual/ instrumentos/sanjose.htm>. Acesso em: 27 set. 2010.

CONVENÇÃO DE ESTRASBURGO (1967). Disponível em: <http://jus.familiae.tripod.com/ id247. html>. Acesso em: 27 set. 2010.

CONVENÇÃO INTERAMERICANA SOBRE CONFLITOS DE LEIS EM MATÉRIA DE ADOÇÃO DE MENORES (1985). Disponível em: < http://www.oas. org/juridico/portuguese/treaties/B-48.htm>. Acesso em: 27 set. 2010.

CONVENÇÃO SOBRE OS ASPECTOS CIVIS DO SEQUESTRO INTERNACIONAL DE CRIANÇAS (1980). Disponível em: <http://www2.mre.gov.br/dai/ seq.htm>. Acesso em: 27 set. 2010. 
CONVENÇÃO INTERAMERICANA SOBRE RESTITUIÇÃO INTERNACIONAL DE MENORES (1979). Disponível em: <http://www.oas.org/juridico/ portuguese/treaties/B-53.htm>. Acesso em: 27 set. 2010.

CONVENÇÃO INTERAMERICANASOBRE TRÁFICO INTERNACIONAL DE MENORES (1994). Disponível em: <http://www2.mre.gov.br/dai/trafico.htm>. Acesso em: 27 set. 2010.

CONVENÇÃO INTERNACIONAL DOS DIREITOS DA Criança (1989). Disponível em: <http://www.unicef. org/brazil/pt/resources_10120.htm>. Acesso em: 27 set. 2010.

CONVENÇÃO RELATIVA À COMPETÊNCIA DAS AUTORIDADES e à Lei Aplicável em Matéria de Proteção de Menores (1961). Disponível em: <http:// jus.familiae.tripod.com/id250. html>. Acesso em: 27 set. 2010.

CONVENÇÃO RELATIVA À PROTEÇÃO DAS CRIANÇAS E A COOPERAÇÃO EM MATÉRIA DE ADOÇÃO INTERNACIONAL (1993). Disponível em: $<$ http://www.edsonseda.com.br/ haia.htm>. Acesso em: 27 set. 2010.

DAVIES, Francisco J. Pilloti. Manual de procedimentos para formação de família adotiva. Montevidéu: Instituto Interamericano del Niño, 1990.

DECLARAÇÃO UNIVERSAL DOS DIREITOS HUMANOS (1948). Disponível em: < http://www. onu-brasil.org.br/documentos_direitoshumanos.php>. Acesso em: 27 set. 2010.

ESTATUTO DA CRIANÇA E DO ADOLESCENTE (1993). In: OLIVEIRA, Thelma A. (Coord. e Org.) et al. Edição Comemorativa 2010: Estatuto da Criança e do Adolescente e Legislação Complementar para a Proteção Integral de Crianças e Adolescentes. Curitiba, Secretaria de Estado da Criança e da Juventude, 2010.

FIGUEIRÊDO, Luiz Carlos de Barros. Adoção Internacional: convenções internacionais. Revista da Escola Superior de Magistratura do Estado de Santa Catarina - EMESC, v.4. Florianópolis, 1998.

GOMIDE, P. I. C. Prefácio. In: WEBER, Lidia N. D. Laços de ternura: pesquisas e histórias de adoção. 2 ed., p. 17-18. Curitiba: Juruá, 1999.

HOUAISS, A. Dicionário Houaiss da língua portuguesa. Rio de Janeiro: Objetiva, 2001.

KALOUSTIAN, Silvio Manoug (Org.). Família brasileira: a base de tudo. São Paulo: Editora Cortez, UNICEF, 1994.
KISTEMANN, FláviaAparecida. Adoção internacional: uma possibilidade de inclusão familiar. 2008. 165 f. Tese (Doutorado em Serviço Social) - Pontifícia Universidade Católica de São Paulo, São Paulo, 2008.

LANE, Silvia. O que é psicologia social? Coleção Primeiros Passos. 15. ed. São Paulo: Brasiliense, 1989.

LIBERATI, Wilson Donizete. Adoção: adoção internacional: doutrina e jurisprudência. 2 ed. São Paulo: Malheiros, 2003.

PACTO INTERNACIONAL DOS DIREITOS CIVIS E POLÍTICOS (1966). Disponível em: <http://www. interlegis.gov.br/processo_legislativo/copy_of_2002 0319150524/20030616104212/20030616113554>. Acesso em: 27 set. 2010.

PACTO INTERNACIONAL SOBRE DIREITOS ECONÔMICOS, SOCIAIS E CULTURAIS (1966). Disponível em: < http://www.domtotal.com/direito/ pagina/detalhe/22778/pacto-internacional-sobre-direitoseconomicos-sociais-e-culturais>. Acesso em: 27 set. 2010.

RIZZINI, Irene (Coord.). Acolhendo crianças e adolescentes: experiências de promoção do direito à convivência familiar e comunitária no Brasil. São Paulo: Cortez; Brasília, DF: UNICEF; CIESPI; Rio de Janeiro, RJ: PUC-RIO, 2006.

SILVA, Alexandra L. G. da. A importância do assistente social no processo de adoção na Vara da Infância e Juventude de Ponta Grossa: particularidades e desafios. Trabalho de Conclusão de Curso (Serviço Social) - Universidade Estadual de Ponta Grossa, Ponta Grossa, 2005.

SOUZA, Renata Pauliv de. Ser filho adotivo. In: SCHETTINI, Suzana Sofia Moeller; SCHETTINI FILHO, Luiz (Org.). Adoção: os vários lados dessa história. Recife: Bagaço, 2006.

VARGAS, Marlizete M. Adoção tardia: da família sonhada à família possível. São Paulo: Casa do Psicólogo, 1998.

VERONESE, Josiane Rose Petry; PETRY, João Felipe Corrêa. Adoção internacional e Mercosul: aspectos jurídicos e sociais. Florianópolis: Fundação Boiteux, 2004.

WEBER, Lidia N. D. Laços de ternura: pesquisas e histórias de adoção. 2 ed. Curitiba: Juruá, 1999

WEBER, Lidia N. D. Pais e filhos por adoção no Brasil. Curitiba: Juruá, 2001. 